\title{
Holiday Effect in the Indonesian Stock Market
}

\author{
Nugroho Sasikirono \\ Department of Management \\ The Faculty of Economics and Business, Universitas \\ Airlangga, Indonesia \\ nugroho69@yahoo.com
}

\author{
Harlina Meidiaswati \\ Departement of Management \\ The Faculty of Economics, \\ Kartini University Indonesia
}

\begin{abstract}
This study aims to assess whether there is any holiday effect in the Indonesian stock market, especially on Eid al-Fitr, Eid al-Adha, Christmas, Easter and Chinese Lunar New Year. Selection of the holiday events is done by considering the number of adherents of the three dominant religion in Indonesia that reached $97.04 \%$ of Indonesia's population, while the Chinese Lunar New Year is celebrated by the ethnic Chinese population of different religious backgrounds. Analyses were performed by regressing dummy of holiday to stock market returns in period $2005-2015$. The results showed that post holiday average market returns 4 times higher than the average return of the other trading days. There are a post-holiday effect with diverse influences. Christmas, Easter and Eid al-Adha show the positive influence, Eid al-Fitr show negative effects, whereas the Chinese Lunar New Year showed no effect. Although the holiday effect occurred in the Indonesian stock market, this anomaly was yet to fully explain the tendency of higher market return after the holidays.
\end{abstract}

Keywords: market ffficiency, market anomaly, holiday effect.

\section{Introduction}

A rational investor in the capital market will consider all relevant information before making certain decisions; the decision to buy, sell, or hold securities. Assuming all investors were rational, it can be argued that securities prices reflect all information. The market is said to be efficient when securities prices reflect all available informations. In efficient capital markets, it is difficult for investors to earn profits above normal levels consistently by conducting transactions on the exchange. In the less efficient capital markets, less securities prices can reflect all the information available or time gaps arise in the process of price adjustment, so it will open up the opportunity for investors to make profits by exploiting the situation.

It has been known three forms of market efficiency, namely: weak, semi-strong and strong efficiency forms. Weak form market efficiency hypothesis states that current prices already reflect all past information of traded securities; namely information on prices and trading volume. An investor in a market with weak form of efficiency can not gain above normal by using certain trading rules based on past trading informations. Nevertheless,results of the studies in the capital markets of various countries has detected some regularity. Such regularity is known as market anomalies. In the event of anomalies, the rate of return on the capital market will be incompatible with the efficient market hypothesis' prediction.

One form of market anomalies, is the tendency to significance differences in stock returns at certain times, which is known as seasonal regularities (Lakonishok and Smidt, 1989) is often called into seasonality. Some forms of seasonality that often observed are: 1) day of the week effect or weekend effect (French, 1980; Gibson and Hess, 1981; Lakonishok and Levi, 1982), 2) monthly effect (Ariel, 1987), and 3) holiday effect (Ariel, 1990; Chan et al., 1996).

Ariel (1990) reported a tendency of higher pre-holiday market returns on the eight holidays in the United States. Studies of the holiday effect on international stock markets find that the holiday effect would occur after a holiday (Picou, 2006). In countries that are characterized by national cultural dimensions of high long term orientation (Hofstede, 2010) holiday effect is related to the religious or cultural holiday events (Chan et al., 1996; Mehran et al., 2012; Yuan and Gupta, 2014).

The existence of seasonality showed the inefficiency of a stock market of a country and ultimately will affect the decisions of investors. Therefore it is quite interesting to examine whether there is any holiday effect in the Indonesian stock market, especially in the religious holidays of four religions with a large enough number of adherents in Indonesia, namely: Islam, Catholicism, Christianity, and Confucianism. Specifically, religious holidays that became the object of study are the Eid al-Fitr, Eid al-Adha, Christmas, Easter and Chinese New Year. Selection of the feast is done by considering the number of adherents of the three dominant religion in Indonesia reached $97.04 \%$ of the Indonesian population (Census 2010 Data - The Central Bureau of Statistics of the Republic of Indonesia), while the Chinese New Year is celebrated by the ethnic Chinese population of different religious backgrounds.

\section{Literature Review}

\section{Efficient Market Hypothesis}

According to Husnan (2005), an efficient capital market is a market where the price of traded securities already reflect all relevant information. According to Fama (1970) the stock price will change only when there is new information, which in essence, can not be predicted in advance. The more complete and faster new information is 
reflected in the price, the more efficient is the capital market. Market's speed in absorbing all of the available information depends on the types of information. Information that needs quick evaluation will have an impact on price changes rapidly (eg in minutes). Other types of information can have longer impact on the market reaction.

Jones (2009) states that an efficient capital market can occur if any of the following conditions:

1. There are rational investors in considerable amounts, oriented towards profit maximization, active and are price takers.

2. The information provided is free and can be accessed easily by the market participants in the relatively same time.

3. The production of the information occur randomly.

4. Investors reacted quickly and appropriately to the emergence of new information.

One implication of efficient capital markets is that any changes in the market price of the next period will really take into account all the information regarding the condition of the market fundamentals that arrived between different time. Fundamental values that arise from the information will be quickly reflected in stock prices, and therefore arbitrage opportunities will be lost. Another implication is that the strategy of the efficient market trading (technical analysis) that is designed to beat the market can not generate profits above normal profits consistently. An investor can not benefit above normal in the long term. This is related to the fact that the possibility that the stock price will rise in the next day is equal to the probability of the price will fall. Hence in the efficient capital market the superior strategy in stock trading is buy and hold.

\section{Market Anomaly}

Several studies conducted by the French (1980), Gibson and Hess (1981), Lakonishok and Levi (1982), Ariel (1987), Ariel (1990) and Chan et al. (1996) showed the presence of anomalies in the capital market in the form of a repeating pattern of returns (regularities). The results generated by the market anomalies are on contrary to what is predicted in the efficient market hypothesis.

One of the form of market anomaly is holiday effect, ie the significance differences of stock return in a few days before or after the holiday compared with an average return of other trading days. Studies in the United States by Ariel (1990) showed that pre-holiday return tend to be more higher than other days return, while studies in six other countries by Picou (2006) indicates that the holiday effect occurs after the holidays.

Study of holiday effect on religious events have been performed in many occasions. Mehran et al. (2012) found that in the American market the average daily return around nine days of religious Jews in are 32 times higher than the average return of other trading day. Religious nuance of celebrations also found to affect the market return, which on the feast of joyful nuances returns tend to rise, while in the feast of the solemn nuances returns tend to fall. Studies by Yuan and Gupta (2014) on stock return of some stock market in East Asian countries and India found a positive effect on pre-Chinese Lunar New Year. Chinese New Year effect was also found in Singapore and Malaysia stock market (Chan et al., 1996). Furthermore, Chan et al. Also found the effect of the Islamic New Year and Vesak; but had no found Eid al-Fitr effect.

\section{Method}

a. Hypothesis:

There is holiday effect in the Indonesian Stock Market 2005-2015

b. Research Variables:

- The dependent variable isThe Indonesian stock market return between 2005 - 2016 .

- The independent variables are pre and post holiday trading day, expressed as dummy variables. The time windows being used for pre and post holiday dummy are 5 and 3 days before and after the holiday.

c. Operational Definition of Variables:

1. Market return is calculated as the percentage change of Composite Stock Price Index (IHSG) on two trading days in a row.

2. Dummy variable is 1 to 5 or 3 trading days before and after religious holidays, and 0 for anothr trading day. There is another dummy variable for types of religious holidays, namely 1 for certain religious holidays and 0 for other trading day.

d. Model of Analysis

1. $R_{m}=\beta_{0}+\beta_{1} D_{\text {PreHol }}+\beta_{2} D_{\text {PosHol }}+e$

2. $R_{\mathrm{m}}=\beta_{0}+\beta_{1} \mathrm{D}_{\text {PreNT }}+\beta_{2} \mathrm{D}_{\text {PosNT }}+\beta_{3} \mathrm{D}_{\text {PreID }}+\beta_{4} \mathrm{D}_{\text {PosID }}+$ $\beta_{5} D_{\text {PreIM }}+\beta_{6} D_{\text {PosIM }}+\beta_{7} D_{\text {PrePs }}+\beta_{8} D_{\text {PosPS }}+$ $\beta_{9} D_{\text {PreAD }}+\beta_{10} D_{\text {PosAD }}+e$

\section{Result}

Table 1

Descriptive

\begin{tabular}{|l|r|r|r|r|r|} 
& \multicolumn{1}{|c|}{ MIN } & \multicolumn{1}{c|}{ MAX } & \multicolumn{1}{c|}{ MEAN } & \multicolumn{1}{c|}{ STDEV } & \multicolumn{1}{c|}{$\mathrm{N}$} \\
\hline RMNoHOL & -0.0888 & 0.0792 & 0.0005 & 0.0130 & 2148 \\
\hline RMPre HOL & -0.0548 & 0.0260 & 0.0001 & 0.0036 & 272 \\
\hline RMPosHOL & -0.1038 & 0.0763 & 0.0022 & 0.0051 & 272 \\
\hline RMPre NT & -0.0312 & 0.0192 & -0.0002 & 0.0014 & 55 \\
\hline RMPosNT & -0.0161 & 0.0604 & 0.0052 & 0.0017 & 55 \\
\hline RMPreID & -0.0168 & 0.0180 & 0.0017 & 0.0012 & 55 \\
\hline RMPosID & -0.1038 & 0.0410 & -0.0040 & 0.0034 & 55 \\
\hline RMPreIM & -0.0258 & 0.0225 & 0.0002 & 0.0015 & 55 \\
\hline RMPosIM & -0.0188 & 0.0248 & 0.0014 & 0.0013 & 55 \\
\hline RMPrePS & -0.0452 & 0.0260 & 0.0016 & 0.0020 & 55 \\
\hline RMPosPS & -0.0272 & 0.0509 & 0.0045 & 0.0018 & 55 \\
\hline RMPreAD & -0.0279 & 0.0212 & -0.0027 & 0.0017 & 55 \\
\hline RMPosAD & -0.0408 & 0.0763 & 0.0041 & 0.0025 & 55 \\
\hline
\end{tabular}

The average post-holiday market as a whole was higher than the average return of pre-holiday and regular day trading returns. Overall post-holiday return four times higher than regular trading days return. In contrast, the average pre-holiday return tend to be lower than the regular trading days return. These conditions, may appear as the effect of pre-holiday selling impulse, followed by postholiday buying. Observations on the trading day before and after each holiday that show that the return is lower in the 
pre-holiday and higher in the post-holiday, were consistent for almost all religious holidays, except for Eid al-Fitr. Since post-Eid, the average return is negative.

Table 2

Overall Pre and Post Holiday Effect

\begin{tabular}{|c|c|c|c|c|}
\multirow{2}{*}{ RM } & \multicolumn{2}{|c|}{ 5 DAYS } & \multicolumn{2}{c|}{3 DAYS } \\
\cline { 2 - 5 } & Koef & Sig & Koef & Sig \\
\hline Constant & 0.054 & ${ }^{*}$ & 0.050 & $*$ \\
\hline DPreHol & -0.046 & ns & 0.056 & ns \\
\hline DPosHol & 0.168 & ${ }^{*}$ & 0.021 & ${ }^{*}$ \\
\hline$R^{2}$ & \multicolumn{2}{|c|}{0.001} & \multicolumn{2}{c|}{0.001} \\
\hline$F$ & \multicolumn{2}{|c|}{ ns } & \multicolumn{2}{c|}{ ns } \\
\hline
\end{tabular}

*) significant at $\alpha 10 \%$

**) significant at $\alpha 5 \%$

**) significant at $0.1 \%$

Tests using different pre and post holiday (5 and 3 days) on the allover holiday showed consistent results. There is a significant positive effect on the trading day after the holiday market return in the Indonesian stock market. It should be underlined the low value of coefficient of determination and no significant simultaneous test, lead to the the higher role of other factors or a need of better model.

Table 3

Pre and Post Holiday Effect

\begin{tabular}{|c|c|c|c|c|}
\hline \multirow{2}{*}{ RM } & \multicolumn{2}{|c|}{5 DAYS } & \multicolumn{2}{|c|}{3 DAYS } \\
\hline & Koef & Sig & Koef & Sig \\
\hline Constant & 0.048 & ns & 0.050 & * \\
\hline DPreNT & 0.021 & ns & 0.109 & ns \\
\hline DPosNT & 0.466 & $\hbar \hbar \hbar$ & 0.697 & $\hbar * \pi$ \\
\hline DPrelD & 0.066 & ns & 0.233 & ns \\
\hline DPoslD & -0.340 & * & -0.812 & $* * *$ \\
\hline DPrelM & -0.005 & ns & 0.173 & $\mathrm{~ns}$ \\
\hline DPos|M & 0.109 & ns & 0.180 & ns \\
\hline DPrePS & 0.109 & ns & 0.058 & ns \\
\hline DPosPS & 0.407 & $* *$ & 0.523 & ** \\
\hline DPreAD & -0.353 & $*$ & -0.321 & $\mathrm{~ns}$ \\
\hline DPosAD & 0.329 & * & 0.503 & ** \\
\hline $\mathrm{R}^{2}$ & \multicolumn{2}{|c|}{0.008} & \multicolumn{2}{|c|}{0.012} \\
\hline $\mathrm{F}$ & \multicolumn{2}{|c|}{$\pi *$} & \multicolumn{2}{|c|}{$\hbar \hbar \hbar$} \\
\hline
\end{tabular}

*) significant at $\alpha 10 \%$

$\$$ ) significant at $\alpha 5 \%$

**) significant at $\alpha 1 \%$

Tests using the various pre and post holiday return show that in general there are significant influence of postholiday trading day on the market return, with the exception of the trading day after the Chinese Lunar New Year that has no effect. Unlike the other holidays, the post-Eid al-Fitr trading day negatively affect the market return. This may be related to the tendency of Indonesian people to extend Eid holiday, which resulted in the slow market recovery followed by a post-holiday selling. Tests on various holidays event were able to increase the coefficient of determination models..

\section{Conclusion}

Just like any other countries, holiday effect occur in Indonesia, where the post-holiday average return 4 times higher than the average return of other trading day. The effect of post-holiday trading day to market return quite diverse. Christmas, Easter and Eid al-Adha show the positive effect, Eid show negative effects, whereas the Chinese Lunar New year showed no effect. Although the holiday effect occurred in the Indonesian stock market, this anomaly was not able to fully explain the tendency of postholiday higher market return.

\section{Reference}

[1] Ariel, R,A. 1987. A Monthly Effect in Stock Returns. Journal of Financial Economics, Vol. 18, Iss. 1, 161 174.

[2] Ariel, R,A. 1990. High Stock Returns before Holidays:Existence and Evidence on Possible Causes. The Journal of Finance, Vol. XLV, No. 5, 1611-1626.

[3] Chan, M.W.L, Khanthavit, A, Thomas, H. 1996. Seasonality and Cultural Influences on Four Asian Stock Markets. Asia Pacific Journal of Management, Vol. 13, No. 2, 1-24.

[4] Chong, R., Hudson, R., Keasey, K., Littler, K. 2005. Pre-holiday Effects: International Evidence on the Decline and Reversal of a Stock Market Anomaly. Journal of International Money and Finance. Vol. 24, pp. 1226-1236.

[5] Fama, Eugene F. 1970. Efficient Capital Markets: A Review of Theory and Empirical Work. The Journal of Finance, Vol. 25, No. 2, pp. 383-417.

[6] French, K. R. 1980. Stock Returns and the Weekend Effect. Journal of Financial Economics, Vol. 8, 55-70.

[7] Gibbons, M. R.. and P. Hess. 1981. Day of the Week Effects and Asset Returns. Journal of Business, Vol. 54, 579-596.

[8] Husnan, Suad. 2005. Dasar-dasar Teori Portofolio dan Analisis Sekuritas, Edisi 5. UPP STIM YKPN, Yogyakarta.

[9] Jogianto. 2010. Teori Portofolio dan Analisis Investasi, edisi 10. BPFE-Yogyakarta.

[10] Jones, Charles P. 2009. Investment: Analysis and Management, 11th edition. Wiley, USA.

[11] Kim, Chang-Wun, and Park,Jinwoo. 1994. Holiday Effects and Stock Returns: Further Evidence. The Journal of Financial and Quantitative Analysis. Vol. 29, No. 1, pp. 145-157.

[12] Lakonishok, J, Smidt, S. 1988. Are Seasonal Anomalies Real? A Ninety-Year Perspective. The Review of Financial Studies, Volume 1, number 4, pp. 403-425. 
[13] Lakonishok, J., and M. Levi. 1982. Weekend Effects on Stock Returns. Journal of Finance, Vol. 37, 883889.

[14] Lahav, E., Shavit, T., Benzion, U. 2016. Can't Wait to Celebrate: Holiday Euphoria, Impulsive Behavior and Time Preference. Journal of Behavioral and Experimental Economics. Vol. 65, pp. 128-134.

[15] Mehran, J, Meisami, A, Busenbark, J.R. 2012. L'Chaim: Jewish Holidays and Stock Market Returns. Managerial Finance, Vol. 38 No. 7, pp. 641-652.

[16] Pantzalis, C., Ucar, E. 2014. Religious Holidays, Investor Distraction, and Earnings Announcement Effects. Journal of Banking \& Finance. Vol. 47, Pp. 102-117.

[17] Picou, A. 2006. Stock Returns Behavior During Holiday Periods: Evidence from Six Countries. Managerial Finance, Vol. 32 No. 5, pp. 433-445.

[18] Raj, M. Kumari, D. 2006. Day-of-the-Week and Other Market Anomalies in the Indian Stock Market. International Journal of Emerging Markets, Vol. 1 No. 3, pp. 235-246.

[19] Schaub, Mark, Lee,B.S., Chun, S.E. 2015. Overreaction and seasonality in Asian stock indices: Evidence from Korea, Hong Kong and Japan. Contemporary Studies in Economic and Financial Analysis. Vol. 93, pp. 405-422

[20] Takato, H., Maberly, Edwin D. 2014. An Analysis of Japanese Return Dinamics Conditional on United States Monday Holiday Closure, in J. Jay Choi, Takato Hiraki (ed.) The Japanese Finance: Corporate Finance and Capital Markets in ... (International Finance Review, Volume 4) Emerald Group Publishing Limited, pp.233 - 249

[21] Vergin, R, McGinnis, J. 1999. Rivisiting the Holiday Effect: Is t on Holiday? Applied Financial Economics, Vol. 9, 477-482.

[22] Yuan, T. Gupta, R. 2014. Chinese Lunar New Year Effect in Asian Stock Markets, 1999-2012. The Quarterly Review of Economics and Finance, Vol. 54, Iss. 4, pp. 529-537. 